\title{
Effect of Method of Secondary Fermentation and Type of Base Wine on Physico-Chemical and Sensory Qualities of Sparkling Plum Wine
}

\author{
Vinod K. Joshi ${ }^{*}$, Sanjeev K. Sharma ${ }^{1}$, Ravinder K. Goyal ${ }^{2}$ and Narayan S. Thakur ${ }^{1}$ \\ ${ }^{I}$ Department of Post-harvest Technology, ${ }^{2}$ Department of Vegetable Crops, Dr YS Parmar University of \\ Horticulture \& Forestry, Nauni-Solan (H.P) 173 230, India
}

\begin{abstract}
Plum base wines prepared with potassium metabisulphite or sodium benzoate were converted into sparkling wine, either by 'Methode Champenoise' or tank method with artificially carbonated wine serving as a control. In both the secondary fermentation methods ethanol and low temperature acclimatized yeast; Saccharomyces cerevisiae UCD-595 with optimized sugar (1.5\%) and di-ammonium hydrogen phosphate $(0.2 \%)$ were used. Both methods of sparkling wine production and the type of base wine affected the physico-chemical and sensory characteristics of the sparkling wine produced. In the secondary fermented wines, most of the physico-chemical characteristics were altered compared to that of artificially carbonated wines except volatile acidity, methanol, propanol and ethanol. Furthermore, these wines contained lower proteins, minerals and amyl alcohol than the base wine. In general, the sparkling wines produced by either of the secondary fermentation method had lower sugar, more alcohol, higher macro elements but lower $\mathrm{Fe}$ and $\mathrm{Cu}$ contents than the artificially carbonated wines. An overview of the changes occurring in the sparkling wine in comparison to artificially carbonated wine revealed that most of the changes took place due to secondary fermentation. The bottle fermented wine recorded the highest pressure, low TSS and sugars. The secondary bottle fermented wine was the best in most of the sensory qualities but needed proper acid-sugar blend of the base wine before conducting secondary fermentation. Sparkling wine made from base wine with sodium benzoate was preferred to that prepared with potassium metabisulphite. The studies showed the potential of plum fruits for production of sparkling wine.
\end{abstract}

Key words: Plum, Prunus salicina L., Sparkling wine, potassium metabisulphite, sodium benzoate, Saccharomyces cerevisiae.

\section{INTRODUCTION}

Plum (Prunus salicina L.) is cultivated all over the world including India (Bhutani and Joshi 1995). Its fruit is considered a potential substrate for the preparation of alcoholic beverags including wine and vermouth because of its attractive colour and good fermentability (Amerine et al. 1980, Vyas and Joshi 1982, Joshi et al. 1991, Joshi 1997). Since the fruit has a very short postharvest life, a large portion of the produce goes waste during peak season. The processing industry, which at present is at growing stage, is mainly confined to the canning and drying of select varieties (Woodruf and Luh 1986). Production of alcoholic beverages from plum could increase the utilization of fruit.
Sparkling wine seems to have a good potential to be a profitable outlet. Champagne is the most popular sparkling wine throughout the world (Lee and Baldwin 1988, Montemiglio 1992) but the technology of champagne making is available only in a few countries especially France. Besides, there are many steps in its production technology with a very limited published information (Amerine et al. 1980). Even out of the scattered information available, a major part is patented. Most of the sparkling wines are produced from grapes. Recently, sparkling wines from orange and elderflower have also been developed (Rose 1992, Dirker 1992). But no information is available on the suitability of plum fruits for the preparation of sparkling wine, its composition and quality of

\footnotetext{
* Author for correspondence
} 
wine made by different methods. We have earlier reported the composition and quality of plum base wine using two different preservatives (Joshi and Sharma 1995). The factors important in secondary fermentation of plum base wine such as yeast acclimatization to ethanol and low temperature fermentability, amount of sugar and nitrogen source required have earlier been reported (Sharma and Joshi 1997). In this paper, we report the results of our study on physico-chemical and sensory qualities of sparkling wines prepared by bottle and tank fermentation methods along with artificially carbonated wines, using two types of base wines - potassium metabisulphite (KMS) and sodium benzoate $(\mathrm{NaB})$ treated.

\section{MATERIALS AND METHODS}

In the preparation of sparkling plum wine two methods; bottle and tank fermentation were used with artificial carbonated wine as a control. The procedure for yeast acclimatization and amelioration with sugar and nitrogen source used were the same as reported earlier (Sharma and Joshi 1997).

Bottle fermentation: KMS and $\mathrm{NaB}$ treated base wines were ameliorated with $1.5 \%$ sugar and $0.2 \%$ di-ammonium hydrogen phsophate (DAHP) and inoculated with acclimatized Saccharomyces cerevisiae var. ellipsoideus UCD-595 (0.3\%, v/v inoculum). After bottling, corking and labelling, the bottles were incubated at $14 \pm 2^{\circ} \mathrm{C}$ for three months, keeping them in slanting position. Afterwards these were placed upside down with neck downward to get the yeast onto the cork as practiced for champagne making (Amerine et al. 1980). These bottles were opened after chilling to remove the sediments and were used for evaluation of various quality parameters after another three months of aging.

Tank fermentation: An autoclave was suitably modified for this purpose. Fermentation was carried out after ameliorating both the base wines, as described for bottle fermentation. After incubation for a period of two weeks at $14 \pm 2^{\circ} \mathrm{C}$, the tank was chilled and the wine was bottled and corked immediately, followed by evaluation after three months of aging in bottles.

Carbonated wine: Before artificial carbonation of plum wine, the total soluble solids (TSS) of both the KMS and $\mathrm{NaB}$ treated wines was raised to $10^{\circ} \mathrm{B}$ by addition of sugar syrup and the these were filtered and chilled. Initial optimization was carried out by carbonating both the wines in a carbonating machine to give a pressure of 30 psi. The machine had all the contact parts of stainless steel.

Physico-chemical analysis: The wines were evaluated for physico-chemical characteristics and sensory quality. TSS, acidity, pH, sugar, crude proteins, preservatives, total anthocyanins and pressure of the wine were measured by the standard procedures (Amerine et al.1980, Rangamma 1986). The ethanol was measured as per the method of Caputi et al. (1968). Methanol and other alcohols in the wines were estimated by GC method as described earlier (Joshi and Sharma 1995). For total phenols, esters, volatile acidity and aldehyde estimation, the prescribed methods were followed (Amerine 1980 et al.). Mineral contents (macro and micro) were analysed by the method reported earlier (Bhutani et al. 1989).

Sensory evaluation: The sensory analysis of wines was conducted by a panel comprising 10 members. Coded samples of the chilled products were presented to the members in separate booths for evaluation. A recommended proforma except with an additional attribute of extent of carbonation was used for evaluation of wines (Amerine et al. 1980). The overall quality of the wines was determined by obtaining a sum of scores (out of maximum score of 20) from all the parameters. The judges served as replications. The data obtained from physico-chemical parameters and sensory qualities were analysed by CRD and RBD, respectively (Cockrane and Cox 1963).

\section{RESULTS AND DISCUSSION}

Physico-chemical characteristics: The data presented in Table 1 show that the tank 
fermented wine retained more sugar as reflected by the total and reducing sugars and TSS than bottle fermented wine. Among the two base wines, sodium benzoate treated wine had higher of these contents. The higher sugar content of tank fermented wine was the consequence of its slower fermentation than bottle fermentation. Overall, reduction in total sugars of the wines obtained by secondary fermentation (bottle or tank) is due to the consumption of sugar by yeast in production of $\mathrm{CO}_{2}$ and ethanol (Markides 1986). $\mathrm{NaB}$ treated wine had signifi-cantly higher acidity than the KMS wine but different methods were indistinguishable in this respect (Table 1). The consumers reportedly prefer sparkling wines of high acidity and acidification of wine with citric acid for carbonation is normally practiced (Amerine et al. 1980). In comparison to the reported values of acidity for champagne, it was higher in plum wine, traceable to the original acidity of the fruit. The $\mathrm{pH}$ of tank fermented wine was significantly higher than that of bottle fermented or artificial carbonated wines, which is in consistence with the $\mathrm{pH}$ values of these wines (Table 1). Under the given conditions, the wine obtained by either method had similar colour as revealed by the red and yellow colour units.

Bottle fermented wine accumulated higher pressure (5.25 psi) than tank fermented wine. Although, the same cuvee was prepared for both the methods, yet it gave different results in two types of fermentations. A low pressure in tank fermented wine in comparison to the bottle fermented wine was due to multiple factors. The size of fermenter (bottle and tank) and the rate of fermentation affect the pressure. The bigger size of fermenter in tank fermented wine coupled with relatively less fermentation, indicated by higher total sugars (Table 1) are responsible for the low pressure in tank fermented wine. Since the use of fermentation tank in the bottling procedure was known to reduce the $\mathrm{CO}_{2}$ pressure (Janke and Rohr 1960), this appears to be the another reason for low pressure. The highest pressure $(60.0 \mathrm{psi})$ obtained in KMS treated bottle fermentation was slightly lower than the commercially prepared champagne (Amerine et al. 1980). The type of base wine and method of secondary fermentation did not affect the residual preservative level. The level was below the permissible limit.

Results also revealed that both the secondary fermented wines had more ethanol than the artificially carbonated wine and KMS treated wines yielded more ethanol than $\mathrm{NaB}$ treated wines (Table 1). Increase in ethanol content of secondary fermented wine is understandable because of re-fermentation of base wine after addition of sugar and nitrogenous source in contrast to the artificially carbonated wine. The methanol content of spark-ling wine was not affected significantly by either the different methods or by the type of wine. Lack of substrate (pectin) for methanol production which is removed from the base wines by clarification after primary fermentation, probably has contributed to this effect. Secondary fermentation led to significantly higher amount of propanol and amyl alcohol than artificially carbonated wines (Table 1). Tank fermented wines contained more amyl alcohol than bottle fermented or artificially carbonated wines and the KMS treated wine contained higher amount of propanol than the sodium benzoate treated wine. These alcohols are the byproducts of alcoholic fermentation (Amerine et al. 1980), because of this, secondary fermented wine contained higher amount of both propyl and amyl alcohol than the artificially carbonated wine. For this parameter, the values for $\mathrm{NaB}$ treated wine out of the two sparkling wines was favourable. Secondary fermentation either in bottle or tank reduced the aldehyde content and enhanced the total esters, total phenols, total anthocyanin and crude protein content of wines, significantly as compared to the artificially carbonated wines. The wines produced from KMS contained more aldehyde, ethanol and esters, but was having less phenols, anthocyanins and crude proteins than that obtained with sodium benzoate. Since low 
Table2: Sensory evaluation of spakling plum wine

\begin{tabular}{|c|c|c|c|c|c|c|c|}
\hline \multirow[t]{3}{*}{ Attribute } & \multirow{3}{*}{$\begin{array}{l}\text { Maximum } \\
\text { Score }\end{array}$} & \multicolumn{6}{|c|}{ Sensory Scores } \\
\hline & & \multicolumn{2}{|c|}{$\mathrm{BFW}$} & \multicolumn{2}{|c|}{ TFW } & \multicolumn{2}{|c|}{$\mathrm{ACW}$} \\
\hline & & KMS & $\mathrm{NaB}$ & KMS & $\mathrm{NaB}$ & KMS & $\mathrm{NaB}$ \\
\hline Colour \& appearance & 2 & 1.48 & 1.61 & 1.40 & 1.60 & 1.42 & 1.50 \\
\hline Extent of carbonation & 2 & 1.40 & 1.59 & 0.86 & 0.74 & 1.43 & 1.53 \\
\hline Aroma \& bouquet & 4 & 3.55 & 3.66 & 3.45 & 3.55 & 3.30 & 3.44 \\
\hline Volatile acidity & 2 & 1.38 & 1.39 & 1.20 & 1.16 & 1.38 & 1.31 \\
\hline Total acidity & 2 & 1.54 & 1.48 & 1.48 & 1.32 & 1.57 & 1.44 \\
\hline Sweetness & 1 & 0.45 & 0.58 & 0.38 & 0.52 & 0.66 & 0.70 \\
\hline Body & 1 & 0.52 & 0.58 & 0.48 & 0.58 & 0.69 & 0.70 \\
\hline Flavour & 2 & 1.52 & 1.62 & 1.47 & 1.58 & 1.52 & 1.59 \\
\hline Bitterness & 1 & 0.62 & 0.65 & 0.60 & 0.54 & 0.46 & 0.43 \\
\hline Astingency & 1 & 0.66 & 0.70 & 0.62 & 0.66 & 0.56 & 0.50 \\
\hline Overall impression & 2 & 1.60 & 1.70 & 1.62 & 1.70 & 1.54 & 1.62 \\
\hline Sum & 0 & & 15.55 & 13.56 & 13.95 & 14.53 & 14.76 \\
\hline
\end{tabular}

BFW :Bottle fermented wine, $\quad$ TFW: =Tank fermented wine, ACW: Artificially carbonated wine, KMS: Potassium metabisulphite trated wine, NaB: Sodium benzoate treated wine

All composition parameters are related with fermentation and thus the change could be correlated with secondary fermentation. Since the wine with KMS had higher fermentability than sodium benzoate, these changes are more pronounced in the KMS wine than sodium benzoate. Among the two methods of secondary fermentation, the bottle fermentation gained most of these characteristics desirable due to better fermentation conditions in the bottle than tank. Tank fermentation method is known to provide more aerobic conditions than bottle giving rise to loss of alcohol, production of more higher alcohols, loss of pressure etc. Bottle fermentation method thus, appears to be the most suitable in this respect.

The secondary fermentation retained higher contents of major elements ( $\mathrm{Na}, \mathrm{K}, \mathrm{C}, \mathrm{Mg}$ ) and trace elements except for $\mathrm{Cu}$ and $\mathrm{Fe}$ as compared to the artificially carbonated wines. The mineral composition of sparkling wine obtained by lether method, however, was more or less similar. The type of base wine had significant impact on mineral contents of the sparkling wine. The sodium benzoate treated wine when compared with KMS treatment contained higher amount of $\mathrm{Na}, \mathrm{K}$ and $\mathrm{Mg}$ and low of $\mathrm{Ca}, \mathrm{Fe}$ and $\mathrm{Zn}$. The difference in contents of other microelements, $\mathrm{Cu}$ and $\mathrm{Mn}$ were non-significant. The difference in elements level may arise due to more than one reasons. Extent of fermentation, degree of autolysis and aging period can influence solubility and precipitation of the elements. Higher $\mathrm{Fe}$ and $\mathrm{Cu}$ content in artificially carbonated wine seems to be the result of contamination of wine with these metals during carbonation. However, low $\mathrm{Fe}, \mathrm{Cu}, \mathrm{Zn}$ and $\mathrm{Mn}$ are desirable for stability and prevention of metallic taste in the wines (Amerine et al. 1980).

Sensory evaluation: Wines produced by different methods were evaluated significantly different in terms of sensory qualities by the judges (Table 2). The bottle fermented wine was adjudged superior in most of the characteristics except sweetness and body. The sparkling wine prepared from the sodium benzoate treated base wine was superior mainly because of aroma and bouquet, astringency and overall impression. The total scores of the wines prepared by both the methods indicate that these were commercially acceptable. Since bottle fermented wine did not score well with respect to acid-sugar balance level, there is a need for its improvement with respect to this attribute. Besides, there was a less stability of $\mathrm{CO}_{2}$ in the wine. Foam stability is a very important characteristic of sparkling wine. It 
improves during aging which is responsible for release of certain compounds including proteins, lipids and polysaccharides that contribute to foam stability.

Better quality of bottle fermented wine could be attributed to the process of yeast autolysis which plays an important role in producing aroma and flavour (Jordan and Napper 1986). It was indicated by the panelist that compared to KMS treated wine, the $\mathrm{NaB}$ treated wine had desirable astringency and smooth taste as was the case with its base wine discussed earlier (Joshi and Sharma 1995).

From this study, it is concluded that the bottle fermented wine made from base wine with sodium benzoate had desirable level of $\mathrm{CO}_{2}$, low aldehyde, higher esters, more crude proteins, better colour, higher sensory qualities than the one obtained by tank fermentation process or that carbonated artificially. Compared to the artificial carbonated wines those with secondary fermentation had many superior characteristics. Since the maturation was done only for three months, a longer period might have produced wine of still better quality. Nevertheless, the plum fruit has a potential to produce sparkling wine by the methode champanoise.

\section{RESUMO}

Os vinhos a base de ameixa preparado com metabisulfito de potássio ou benzoato de sódio foram convertidos em vinhos espumantes pelo método "Champenoise" ou método de tanque, usando vinho carbonatado artificialmente como controle. Em ambos métodos a fermentação secundária do ethanol a baixa temperatura aclimatizou a levedura Saccharomyces cerevisiae UCD-595 utilizando $1.5 \%$ de açúcar e $0.2 \%$ de fosfato di-amônio de hidrogênio. Não foi verificado nenhum tipo de alteração físicoquímica ou sensorial em nenhum dos métodos utilizados para a produção do vinho espumante Foram verificadas alterações físico-químicas na fermentação secundária do vinho espumante quando comparado com o vinho carbonatado artificialmente, exceto acidez volátil, metanol, propanol e ethanol. Além do mais, estes vinhos contiveram concentrações inferiores de proteínas, minerais e álcool amílico que o vinho de base. Em geral, os vinhos espumantes produzidos por qualquer método de fermentação secundária apresentaram açúcar residual baixo, concentrações elevadas de álcool, macroelementos elevados e concentrações baixas de $\mathrm{Fe}$ e $\mathrm{Cu}$ nos vinhos carbonatados artificialmente. Uma visão geral das mudanças que ocorrem no vinho espumante em comparação ao vinho carbonatado artificialmente demonstrou que a maioria das mudanças ocorreu devido a fermentação secundária. A garrafa do vinho fermentado registrou pressão elevada, TSS e açúcares residuais reduzidos. O Vinho espumante produzido utilizando benzoato de sódio foi preferido em relação ao preparado com metabissulfito de potássio. Esses estudos demostraram o potencial do uso de frutas como ameixa na produção de vinho espumante.

\section{REFERENCES}

Amerine, M. A., Kunkee, R. E., Ough, C. S., Singleton, V. L. and Webb, A. D. (1980), Technology of Wine Making. AVI Publishing Company, Westport, CT, pp. 794

Bhutani, V.P. and Joshi, V.K. (1995), Plum. In: Handbook of Fruit Science and Technology, Cultivation, Storage and Processing. ed. Salunkhe, D.K. \& Kadam, S.S. (Ed.)Mercel Dekker, USA, pp. 203-241

Bhutani, V.P., Joshi, V.K. and Chopra, S.K. (1989), Mineral contents of fruit wines produced experimentally. J. Food Sci. Technol., 26, 332-333.

Caputi, A. Jr., Ueda, M. and Brown, J. (1968), Spectrophotometric determination of ethanol in wine. Am. J. Enol. Vitic., 19, 160-165

Cockrane, W.G. and Cox, G.M. (1963), Experimental designs. 4th edn. Asia Publishing House, Bombay

Dirker, A. (1992), Sparkling elder flower wine. German Federal Republic Patent DE 4119352 C1. FSTA, 24, 8H205

Janke, A. and Rohr, M. (1960), Uber einem Kontrollierten Vergeleichsversuch Tankgarver-fahren/Flaschengarverfhren, Mitt. Rebe. Wein. Ser. A., 10, 210-217. 
Jordan, A. D. and Napper, D. H. (1986), Some aspects of the physical chemistry of bubble and foam phenomenon in sparkling wine. In: Proceedings of Sixth Australian Wine Industry Technical Conference, Adelaide, 14-17 July, Australian Industrial Publishers, Adelaide, pp. 237-246

Joshi, V.K., Attri, B.L. and Mahajan, B.V.C. (1991), Studies on the preparation and evaluation of vermouth from plum. J. Food Sci. Technol., 28, 138-141

Joshi, V.K.(1997), Fruit Wines. Directorate of Extension Education. Dr YS Parmar University of Horticulture \& Forestry, Solan (HP) India

Joshi, V.K. and Sharma, S. K. (1995), Comparative fermentation behaviour, physico-chemical and sensory characteristics of wine as effected by the type of preservatives. Chemie Microbiologie Der Labensmittl, 17, 45-53

Lee, T.H. and Baldwin, G. E. (1988), Developments in the production and consumption of sparkling wines in Australia. Food Technology Australia, 40, 138-140.

Leroy, M.J., Charpentier, M., Duteurtre, B., Feuillat, M. and Charpentier, C. (1990), Yeast autolysis during champagne aging. Am. $J$. Enol. Vitic., 41, 21-28.

Montemiglio, L. (1992), Italian sparkling wines : breakdown of the major international markets. Enotecnico, 28, 57-70.

Ranganna, S. (1986), Handbook of Analuysis and Quality Control for Fruit andvvegetable Products, 2nd. edn. Tata McGraw Hill Publishing Co., New Delhi

Rose, R. (1992), Orange based sparkling alcoholic beverage. French Patent Application FR 2657878 Al. (FSTA, 24, 2H 88)

Sharma, S.K. and Joshi, V.K. (1997), Optimization of some parameters of secondary fermentation for production of sparkling wine. Indian J. Exp. Biol., 34, 235-38

Vyas, K.K. and Joshi, V.K. (1982), Plum wine making- standardization of a methodology. Indian Food Packer, 36, 8086.

Woodruf, J.G. and Luh, B.S. Commercial fruit processing. AVI Publishing Co., Westport, Connecticut, 1986.
Received August 31, 1999; Revised September 21, 1999; Accepted October 05, 1999. 